\title{
The Relationship between the Type of High School and the Students' English Language Proficiency
}

\author{
Mohammad Reza Ghamari (Corresponding author) \\ Dept. of Language and Literature, Amin Police University \\ PO Box 1486767451, Tehran, Iran \\ Tel: 98-912-7044-152Ｅ-mail: dr_m_rezaghamary2@yahoo.com \\ Farzad Hosseini \\ Dept. of Language and Literature, Amin Police University \\ PO Box 71588-16855, Tehran, Iran \\ Tel: 98-921-1261-950Ｅ-mail: farzadhosseini_sh@yahoo.com
}

Received: July 1, 2016 Accepted: July 19, 2016 Published: July 20, 2016

doi:10.5296/ijele.v4i2.9754 URL: http://dx.doi.org/10.5296/ijele.v4i2.9754

\begin{abstract}
This study investigated the English language learning status in 18 high schools in Tehran, Iran. The aim was to examine the extent to which the students have achieved English proficiency, due to the type of high school (non- profit and ordinary-governmental) in which they studied. Also, an attempt was made to explore whether the student' performance on vocabulary, listening, speaking, reading, and writing would be different in terms of students' attendance in language institutes. Furthermore, in this study, the subjects' attitude toward English and its effect on the skills was taken into account.
\end{abstract}

Keywords: Language skills, Language proficiency, Language learning, High school 


\section{Introduction}

There are different ideas about the purpose of high schools. According to the mental disciplinarians, the great purpose of schooling was intellectual development. Many analysts of secondary education considered, "intellectual development vital but they believed it had to be reconciled with the school as a social institution and its place in the larger social order" (Kliebard, 1995).

Middlewood and Burton (2001) argued that most education systems and the curricula which they deliver in the western world have, at least, been shaped by three main sets of ideas. The first is that education is and should be a process of induction to the norms and values of society. The curriculum will reflect such norms of utility and will select and differentiate as well as socialize children into adult roles; the second is that education is a process of seeking the truth through the accumulation of high level disciplined knowledge based on critical analysis of conventional wisdom. The curriculum will be shaped by a pursuit of such knowledge and will differentiate students according to their ability to cope with a critical, analytical search for truth; the third is that the educative process is one of spontaneous natural development. Here the curriculum will support and facilitate this natural process and insure that children reach their maximum potential. Egan (1999) claims that nearly all modern conceptualizations of education from the most radical to the most conservative to be constructed from these three ideas.

Tomlinson (1998) argued that new forms of school organization had to evolve as schools become more responsive to the needs of pupils, less constrained are traditional subjects' boundaries and timetables and where they needed to cooperate more effectively with each other and the wider community.

Although some reviewed the social function of schooling in terms of social reform (Cremin, 1961), the dominant theme was that of "schools as an instrument of social control" (Kliebard, 1995 , p. 81). Social efficiency, in turn, became the "prominent school of thought in influencing the development of the high school" (Spring, 1990, p. 201). Social efficiency, as Murphy (2001) pointed out, meant fundamentally that the function, of high schools would be to prepare for the new industrial world.

Advocates of the new goal of social control wanted education to produce individuals who were trained for a specific role in society and who were willing to work cooperatively in that role.

Therefore, the aim of social control and the educational philosophy of social efficiency combined to create a remarkably firm framework for the construction of the comprehensive high school, and they imposed considerable influence over the shape and texture of the secondary school curriculum. Murphy et al., (2001) argue that the building blocks in the curricular triangle of the modern high school are: (a) practical concerns, (b) social needs and (c) students' needs and interests. This curricular triangle that covers language proficiency is supposed to determine the extent to which the high school students have reached the aim.

A test of language proficiency involves two modules (Jackman \& Mcdowell, 2001): the 
general training module and the academic module. In this study only the general training module of the high school students' English proficiency was examined.

Second language proficiency ranges from zero to full bilingual proficiencies. There is not a fixed rating scale. Trim (1973) recognizes five levels of language proficiency: 1 . Threshold 2. Basic, 3.General competence 4.Advanced to guide any test - maker in the process of assessment, and he believes the numerous test designers utilize the guidelines as a standard for assessment.

A test of IELTS (international English testing system) as one of the best known rating scales employed in this study distinguishes nine classes of proficiency. The subjects' performance rated in each skill on a scale of 9 to 1 putting them in one of the following nine classes:

9. Expert user, 8. Very good user, 7.Good user, 6.Competent user, 5.Modest user, 4.Limited user, 3.Extremely limited user, 2.Intermittent user, 1. Non user (Jackman \& Mcdowell, 2001).

In the present study, all the subjects must take a test for each of the four language skills, i.e. listening, reading, writing and speaking. The test will consist of a score in each of the four skills, which is then averaged to give the overall band score or final mark.

Performance is rated in each skill on the scale of 9 to 1 . How the obtained scores match each of the 9 classes or levels, appear in the section titled scoring. As a general rule, scores below 5 in any one skill are considered too low for academic study. Overall band scores of 5 or 6 are border line.

\subsection{The Purpose of the Study}

In this study three major questions are addressed. The first question tries to find out whether or not the current high schools' curriculum provides students with a satisfactory English proficiency level. To do so, the students' performance on English proficiency is examined due to the above mentioned nine levels.

The second question is concerned with an attempt to see if there is any difference between the students who attended the non-profit high schools as far as the general training module of English proficiency is concerned.

The third major question involves the performance of English proficiency of the students who attended language institutes compared to those who didn't.

\section{Methodology}

\subsection{Subjects}

Around 330 male and female students in grade 3 of 18 high schools participated in this study. They were majoring in mathematics-physics. The schools included 18 ordinary-governmental and nonprofit high schools from 5 geographical districts (north, south, east, west and center) of Tehran. All of the subjects were about to graduate from high school. They had passed English book 1 and 2 and they were studying English book 3 in the time of the test. 


\subsection{Materials}

The materials used in this study included a test of IELTS (International English Language Testing System) followed by an attitude questionnaire. The test covered listening, reading, writing and speaking skills, respectively. They were preceded by a separate vocabulary test as a warm up.

Regarding listening comprehension, the students listened to a tape based on which they either wrote or marked the correct answer. To test reading, the subjects had to read a passage selected from their course book. They were to write a text for writing skill about a predetermined topic. To test speaking, a semi-structured interview was conducted.

\subsection{Procedure}

\subsubsection{Data Collection}

The tests were administered during the normal class hours. The measures employed in this study included the tests of listening, speaking, reading and writing of the general training module of IELTS preceded by a test of vocabulary as a warm up. It was not taken into account in the Overall Band Score.

Since a usual test of IELTS was too time-consuming, the questions were randomly divided by two, and so were asked at the allocated time. Thus, the questions were randomly divided by two, and so was the time allocated.

Through a pilot study it was realized that subjects were more at ease in writing their answers on the question rather than on a separate answer sheet.

The tests were administered at four stages. To test listening and reading the participants had to either fill in the blanks or mark the appropriate answer. They listened to a tape only once. It took 15 minutes. The reading passage contained 250 words. To test writing, the students had to write a text not less than 200 words.

\subsubsection{Scoring}

The subjects received one point for each correct item. There were no negative points for the wrong answers.

The initial four parts included a listening test for which the participants listened to two separate sections and answered 20 questions as they listened. The test took about 8 minutes plus transfer time. The subjects could receive 20 points. The points were divided by nine (the nine classes recognized by IELTS), the result of which could place each student's performance in one of the 9 already mentioned classes.

The name scoring procedure was also applied to the reading skill. It covered a passage for which the subjects had 30 minutes to read and answer 20 questions. The third part included the writing skill. The participants had to complete a writing task. The test required a passage containing 100 words to be written in 15 minutes. The assessment was based on the examiner's judgment. 


\section{Macrothink}

To test the speaking skill, the subjects had to talk to the examiner for about 5 minutes. They had to answer similar questions. Those who took part in the interview were not allowed to consult others who had not participated until then. Again, the assessment appeared to be subjective.

The result will consist of a score for each of the four skills, which is then averaged to give the overall band score or final mark. Performance is rated both for one skill (see table 1) and for all skills (see table 2) on a scale of 9 classes or levels introduced in the introduction of this study.

The score allocated to each skill was divided by nine to determine the class to which any subject's performance on any skill might belong. To do so, the obtained score in each skill was matched with one of the nine classes or levels.

Table 1. The nine levels recognized by IELTS due to the range of possible scores

\begin{tabular}{|c|c|c|c|c|c|}
\hline Level & 1 & 2 & 3 & 4 & 5 \\
\hline Score & $0-22.22$ & $2.23-4.44$ & $4.45-6.66$ & $6.67-8.88$ & $8.89-11.10$ \\
\hline Level & 6 & 7 & 8 & 9 & \\
\hline Score & $11.11-13.32$ & $13.33-15.54$ & $15.55-17.76$ & $17.77-19.98$ & \\
\hline
\end{tabular}

Also, the Overall Band Score of the four skills was divided by 9 to determine the class to which each subject's total performance might belong. The obtained Overall Band Score was then matched with the 9 classes (see the following table).

Table 2. The nine levels recognized by IELTS due to the range of possible Overall Score

\begin{tabular}{|l|c|c|c|c|c|}
\hline Level & 1 & 2 & 3 & 4 & 5 \\
\hline Score & $0-8.8$ & $8.9-17.7$ & $17.8-26.6$ & $26.7-35.5$ & $35.6-44.4$ \\
\hline Level & 6 & 7 & 8 & 9 & \\
\hline Score & $44.5-53.3$ & $53.4-62.2$ & $62.3-71.1$ & $71.2-80$ & \\
\hline
\end{tabular}

\subsection{Data Analysis}

The results were computed by an analysis of one-way ANOVA. It should determine whether the difference, if any, among the performances of groups of subjects due to the variables was significant. The means of the subject's responses in each school concerning each skill appear in table 3 .

The ANOVA revealed whether or not the difference, if any, between the means obtained by the students of nonprofit high schools approaches significance. The ANOVA indicates that the difference among the scores obtained by students in schools located in different regions of the city is significant. In other words, the difference in all skills and among different schools locating in different districts of the city is significant. Due to reading and speaking skills, 
students' attendance in language institutes and their interest toward English, the difference is also significant.

Meanwhile, regarding the writing and listening skills in the four parts of the city the difference is significant.

The means obtained through the subjects' performance determined the level in which the students of any specific high school would lie. The 20 points allocated to each skill are divided into 9 classes which were introduced by IELTS (see table 1).

The correlation coefficient was used to find out the relationship between the subjects' attendance in language institutes and their performance to listening comprehension, speaking, reading and writing skills. An English alphabet letter has represented each high school in table 3 .

\section{Results and Findings}

\subsection{The Students' Performance on the Four Skills, Their Attendance in Language Institutes and Their Attitude towards English}

Regarding listening there is no significant difference between nonprofit high school students' performance and that of the students in the state schools. However, there is a significant difference among the students' performance on reading and writing in nonprofit high schools and that of students in the state schools (see table 3).

Also, more students of nonprofit high schools attended language institutes compared to their counterparts in the state schools.

Both the nonprofit high school students and the students in the state schools provided the researcher with positive responses regarding questions about their interest toward learning English and no significant difference was observed.

The results also indicate that there is a positive relationship between students' attendance in language institutes and their performance on the variables, except the writing skill. The longer students have attended language institutes, the more successfully they have performed on the skills.

The results do not show any significant relationship between students' performance on listening and their interest toward English. However, there is a positive relationship between students' performance on reading, writing and speaking and their interest towards English.

\subsection{Students' Attendance in Language Institutes Due to Their Gender}

Chi-square measured based on subjects' gender shows that the difference between the male and female subjects in districts 1, 6, 9, 1, 7 is not significant as far as attending language institutes is concerned. However, the difference between male and female subjects in district 13 is significant. In this region boys attended the language institutes more than girls.

Due to the subjects' gender, the results indicate in none of the districts there is a difference between boys and girls as far as their attitude towards English is concerned. 


\subsection{Subjects' Performance Due to the District in which the High Schools Are Located}

Regarding listening, students in districts 1, 13, 17 performed similarly. Students in districts 9 and 6 got the lowest scores and district 1 got the highest score of the skill.

Based on the results on the test of reading, students in district 1 got the highest and students in district 17 got the lowest score of the skill.

Due to the test of writing, students in districts 6 and 9 performed the highest and the lowest levels, respectively. Students in districts 13 and 17 performed almost equally.

Taking the results of speaking into account, students in districts 1 and 9 got the highest and lowest levels respectively. District 6 owns the most.

The highest and lowest numbers of students attending language institutes belong to districts 6 and 17, respectively. Also, the highest rate of students' interest in English belongs to students in district 9.

\begin{tabular}{|c|c|c|c|c|c|c|c|}
\hline \multirow{2}{*}{$\begin{array}{l}\text { High } \\
\text { school }\end{array}$} & \multicolumn{5}{|c|}{ The means of the skills } & & \\
\hline & $\begin{array}{c}\text { Vocabular } \\
y\end{array}$ & $\begin{array}{l}\text { Listenin } \\
\mathrm{g}\end{array}$ & Reading & Writing & Speaking & & \\
\hline A & 13.9 & 4.86 & 8.60 & 6.66 & 8.60 & \multirow{4}{*}{$\begin{array}{l}\text { District1 } \\
\text { (North) }\end{array}$} & Nonprofit high schools for boys \\
\hline $\mathrm{B}$ & 14.88 & 5.47 & 8.41 & 8.05 & 8.88 & & Nonprofit high schools for girls \\
\hline $\mathrm{C}$ & 12.73 & 3.46 & 6.00 & 2.73 & 5.53 & & $\begin{array}{l}\text { Ordinary-governmental high } \\
\text { schools for boys }\end{array}$ \\
\hline $\mathrm{D}$ & 14.89 & 4.94 & 8.07 & 6.94 & 7.84 & & $\begin{array}{l}\text { Ordinary-governmental high } \\
\text { schools for girls }\end{array}$ \\
\hline $\mathrm{E}$ & 16.80 & 4.40 & 6.03 & 9.13 & 9.13 & \multirow{4}{*}{$\begin{array}{l}\text { District6 } \\
\text { (Center) }\end{array}$} & Nonprofit high schools for boys \\
\hline $\mathrm{F}$ & 15.05 & 4.10 & 8.10 & 8.89 & 5.71 & & Nonprofit high schools for girls \\
\hline G & 16.00 & 5.06 & 6.33 & 5.13 & 7.26 & & $\begin{array}{l}\text { Ordinary-governmental high } \\
\text { schools for boys }\end{array}$ \\
\hline $\mathrm{H}$ & 14.71 & 1.80 & 5.23 & 7.42 & 6.04 & & $\begin{array}{l}\text { Ordinary-governmental high } \\
\text { schools for girls }\end{array}$ \\
\hline I & 14.33 & 3.77 & 7.50 & 8.33 & 6.22 & \multirow{4}{*}{$\begin{array}{l}\text { District } 6 \\
13 \text { (East) }\end{array}$} & Nonprofit high schools for boys \\
\hline $\mathbf{J}$ & 12.94 & 2.77 & 5.55 & 5.27 & 5.16 & & Nonprofit high schools for girls \\
\hline $\mathrm{K}$ & 15.00 & 5.50 & 6.00 & 6.55 & 7.30 & & $\begin{array}{l}\text { Ordinary-governmental high } \\
\text { schools for boys }\end{array}$ \\
\hline $\mathrm{L}$ & 14.40 & 3.73 & 4.63 & 5.53 & 6.00 & & $\begin{array}{l}\text { Ordinary-governmental high } \\
\text { schools for girls }\end{array}$ \\
\hline M & 15.80 & 2.53 & 2.23 & 6.26 & 6.46 & \multirow{4}{*}{$\begin{array}{l}\text { District } 9 \\
\text { (West) }\end{array}$} & Nonprofit high schools for boys \\
\hline $\mathrm{N}$ & 15.93 & 1.86 & 4.16 & 8.13 & 8.60 & & Nonprofit high schools for girls \\
\hline $\mathrm{O}$ & 9.75 & 2.37 & 7.50 & 3.43 & 1.62 & & $\begin{array}{l}\text { Ordinary-governmental high } \\
\text { schools for boys }\end{array}$ \\
\hline $\mathrm{P}$ & 12.84 & 1.10 & 3.52 & 5.36 & 3.13 & & Ordinary-governmental high \\
\hline
\end{tabular}




\begin{tabular}{|c|c|c|c|c|c|c|c|}
\hline & & & & & & & schools for girls \\
\hline $\mathrm{Q}$ & 14.71 & 4.10 & 4.83 & 5.60 & 6.14 & District 17 & $\begin{array}{c}\text { Ordinary-governmental high } \\
\text { schools for boys }\end{array}$ \\
\cline { 1 - 5 } $\mathrm{R}$ & 13.56 & 3.96 & 4.27 & 7.42 & 9.18 & $\begin{array}{c}\text { (south) } \\
\text { Schdinary-governmental high } \\
\text { schools for girls }\end{array}$ \\
\hline
\end{tabular}

Table 3. The means scores arranged in 9 levels

\begin{tabular}{|c|c|c|c|c|c|c|c|c|c|}
\hline Levels & 1 & 2 & 3 & 4 & 5 & 6 & 7 & 8 & 9 \\
\hline Means & $0-1.99$ & $2-3.99$ & $4-5.99$ & $6-7.99$ & $8-9.99$ & $10-11.99$ & $12-.13 .99$ & $14-15.99$ & $17-20$ \\
\hline
\end{tabular}

\subsection{Students'Proficiency Levels}

The listening mean score (3.71) obtained by the students of nonprofit high schools, which were represented by A, B, E, F, I, J, M, N, conforms to level 2 of IELTS English proficiency.

The listening mean score (3.63) obtained by the students of state schools, which were represented by C, D, G, H, L, O, P, Q, R, conforms to level 2 of the English proficiency test of IELTS (see table 4).

The reading mean score (6.59) obtained by the students of nonprofit high schools, which were represented by A, B, E, F, I, J, M, N, conforms to level 4.

The reading mean (7.05) obtained by the students of state schools which were represented by C, D, G, H, K, L, O, P, Q, R, conforms to level 4.

The writing mean score (7.58) obtained by the students of nonprofit high school were represented by A, B, E, F, I, J, M, N, confirms to level 4.

The writing mean score (7) obtained by the students of state schools which were represented by C, D, G, H, K, L, O, P, Q, R, conforms to level 4.

The speaking mean score (7.09) obtained by the students of nonprofit high schools which were represented by A, B, E, F, I, J, M, N, conforms to level 4.

The speaking mean score (6.02) obtained by the students of state schools which were represented by C, D, G, H, K, L, O, P, Q, R, conforms to level 4.

Table 4. Proficiency levels in which the students are put due to the score of the skill they acquired.

Nonprofit high schools Ordinary-governmental high school

\begin{tabular}{|l|l|l|l|l|l|l|l|l|}
\hline $\begin{array}{l}\text { Skills } \\
\text { levels }\end{array}$ & Listening & Speaking & Reading & Writing & Listening & Speaking & Reading & Writing \\
\hline
\end{tabular}




\begin{tabular}{|c|c|c|c|c|c|c|c|c|}
\hline 9 & & & & & & & & \\
\hline 8 & & & & & & & & \\
\hline 7 & & & & & & & & \\
\hline 6 & & & & & & & & \\
\hline 5 & & & & & & & & \\
\hline 4 & & $\downarrow$ & $\downarrow$ & $\diamond$ & & $\downarrow$ & $\downarrow$ & $\downarrow$ \\
\hline 3 & & & & & & & & \\
\hline 2 & $\downarrow$ & & & & $\downarrow$ & & & \\
\hline 1 & & & & & & & & \\
\hline
\end{tabular}

\section{Conclusion and Recommendations}

The present study tried to determine the junior high school students' English proficiency levels to which they might belong. Although the students of nonprofit high schools outperformed those of state schools in most skills, the difference was not so much to put them in different proficiency levels. Regarding listening comprehension, both groups belonged to level 2, which was far from the ideal proficiency level. However, regarding reading comprehension, writing and speaking, both groups received level 4 which indicates not enough but reasonable degree of language ability on the part of the students.

All students demonstrated high motivation and positive attitude towards learning English. Students' attendance in language institutes provided them with a better performance on listening, speaking and reading comprehension skills.

Based on the findings of this research, in the current educational system, high school students are only familiarized with the four major skills. The results of this study are limited to the general training module. Based on the results of this study one may not conclude about the English proficiency of the high school students in general. However, one might conclude that regarding the general training, more attention should be paid to high schools.

Further research is recommended to replicate the study utilizing the academic module considered as the second module of the English proficiency test of IELTS.

\section{References}

Brown, H. D. (2001). Teaching by principles. NY. Longman.

Cremin, L. A. (1961). The transformation of the school: Progressivism in American Education 1876-1957. New York: Vintage.

Contant, J. B. (1967). The American High School Revised. New York: McGraw-Hill.

Egan, K. (1999). Education's three old ideas and better idea. Journal of Curriculum Studies, 31(3), 257-267. http://dx.doi.org/10.1080/002202799183115 


\section{Macrothink}

Jackman, V., \& Mcdowell, C. (2001). Cambridge Practice Tests for IELTS (1). Cambridge: Cambridge University Press.

Kliebard, H. M. (1995). The struggle for the American Curriculum 1893-1958 (2 ${ }^{\text {nd }}$ ed.). New York: Routledge.

Middlewood, D., \& Burton, N. (2001). Managing the Curriculum. London: Paul Chapman Publishing. PMid:11738166

Murphy, J. (2001). The productive high school: Creating personalized academic communities. Corwin Press.

Spring, H. (1990). Secondary education in American education (2 ${ }^{\text {nd }}$ ed.). New York: Longman.

Tomlinson, J. (1986). Crossing the bridge, Sheffield City Polytechnic. Sheffield Papers in Educational Management.

Trim, J. L. (1973). Draft Outline of a European Units/Credits System for Modern Languages Learning by Adults.

\section{Copyright Disclaimer}

Copyright for this article is retained by the author(s), with first publication rights granted to the journal.

This is an open-access article distributed under the terms and conditions of the Creative Commons Attribution license (http://creativecommons.org/licenses/by/3.0/). 